\title{
Innowacyjne połączenie kolejowe największych portów lotniczych w Polsce
}

http://dx.doi.org/10.18778/8142-085-3.11

Dawid Gepfert, Dominik Trypuz

Katedra Logistyki i Transportu Przemysłowego, Wydział Transportu

Politechnika Śląska

\section{Wstęp}

Po roku 1989 rozwój transportu kolejowego w Polsce nabrał szybkiego tempa. Oczywiście, nie powinno się porównywać rozwoju transportu kolejowego w Polsce z innymi krajami Europy Zachodniej lub krajami takimi jak Japonia czy Chiny, w których testowanie kolei dużych prędkości prowadzi się od dawna. W ostatnich latach Polska zaopatrzyła się jednak w dostateczną liczbę nowych pociągów, co pozwala na rozwój koncepcji intermodalności.

30 maja 2011 r. PKP Intercity podpisały z przedsiębiorstwem Alstom Transport kontrakt o wartości $665 \mathrm{mln}$ euro (2,64 mld zł) na dostawę 20 siedmioczłonowych pociągów New Pendolino bez mechanizmu przechyłu nadwozia oraz budowę zaplecza technicznego w Warszawie, przeznaczonego wyłącznie dla potrzeb utrzymania taboru kolei dużych prędkości (Rząsa, 2011). Do końca 2013 roku do Polski dotarły cztery pociągi. 6 maja 2014 roku minął termin przekazania ośmiu pierwszych Pendolino, składy nie zostały jednak dostarczone ze względu na problemy z otrzymaniem homologacji. Ostatecznie 11 września 2014 pierwsze ze składów otrzymały świadectwo tego typu wydane przez Urząd Transportu Kolejowego. We wrześniu 14 składów znajdowało się fizycznie w Polsce, a w połowie października pierwsze 2 składy zostały odebrane przez PKP IC. Do dnia rozpoczęcia kursów z pasażerami (14 grudnia 2014 r.) odebrano 15 składów (Rydzyński, 2014). Warto wspomnieć, że 24 listopada 2013 r. w Polsce Pendolino ustanowiło rekord prędkości pojazdu szynowego na torach Europy Środkowo-Wschodniej wynoszący $293 \mathrm{~km} / \mathrm{h}$.

Kolejną większą inwestycją był zakup przez PKP Intercity 20 pociągów produkcji Pesa Dart. Inwestycja rozpoczęła się podpisaniem 23 maja 2014 r. umowy na 20 pojazdów oraz piętnastoletni serwis. Ostatecznie pierwszy Dart został dostarczony 2 grudnia 2015 r., a ostatni, czyli dwudziesty pojazd, 5 marca 2016 r.

Jednocześnie widoczna jest cała sieć połączeń szybkich kolei w Polsce. Do najważniejszych należy linia kolei dużych prędkości „Y”, łącząca Warszawę, Łódź, Kalisz/ 
Ostrów Wielkopolski, Wrocław oraz Poznań. Linia „Y” miałaby poprzez zmodernizowany łącznik Łódź-Opoczno współpracować z Centralną Magistralą Kolejową, co umożliwiłoby połączenia do Katowic i Krakowa (Raczyński, 2008: 17-26).

21 grudnia $2014 \mathrm{r}$. PKP PLK podpisały z hiszpańskim konsorcjum Idom Inżynieria Architektura i Doradztwo i Idom Ingenieria y Consultoria kontrakt na opracowanie wstępnego studium wykonalności dla przedłużenia KDP Warszawa-Łódź-Poznań/Wrocław do Berlina i Pragi ${ }^{1}$.

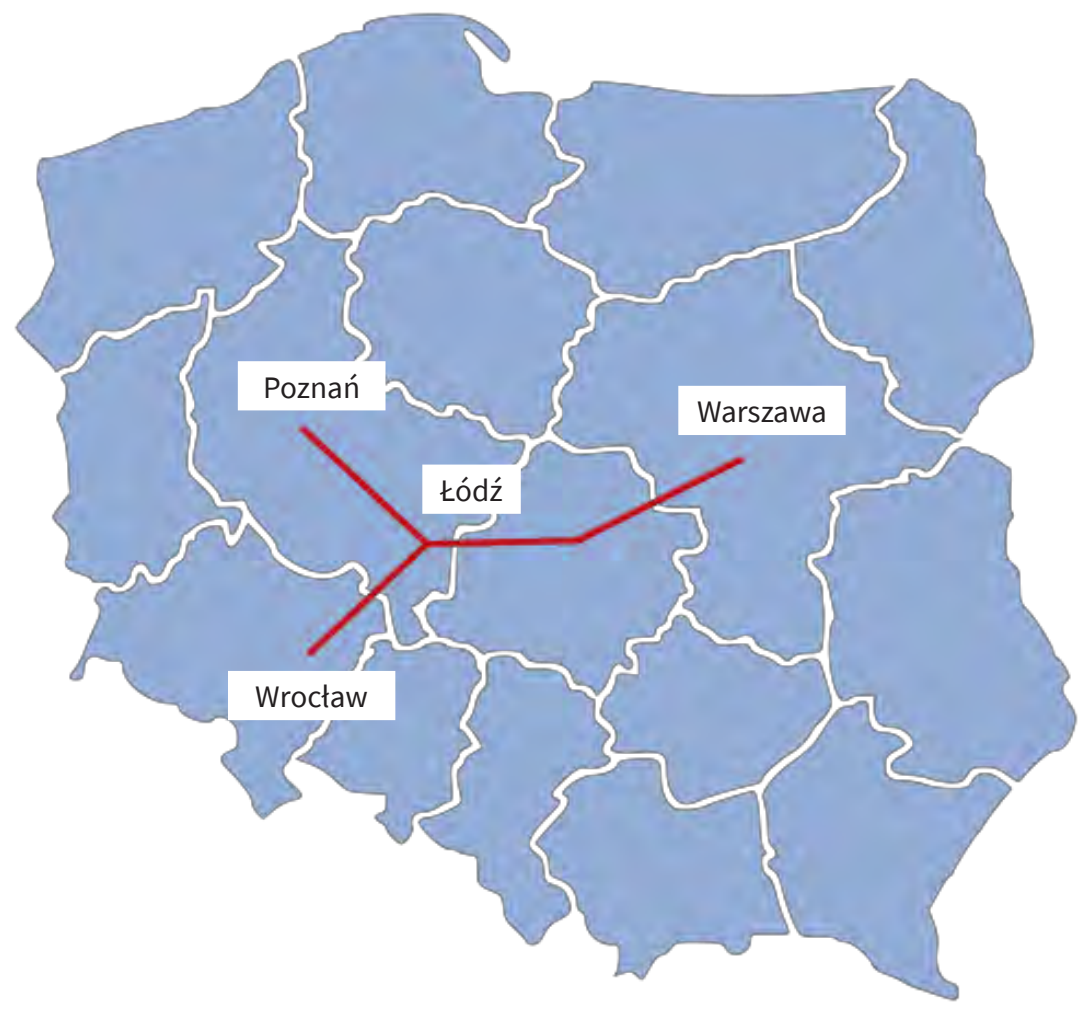

Rysunek 1. Planowana linia kolei dużych prędkości „Y”

Źródto: opracowanie własne na podstawie: https://pl.wikipedia.org/wiki/Plik:POL_rail_Y.svg [dostęp 28.03.2017].

Jednym z kierunków rozwoju portów lotniczych, zapisanych w polityce transportowej kraju, jest włączanie lotnisk w sieć krajową i unijną transportu intermodalnego. Strategia ta wpisuje się w założenia Komisji Europejskiej, która dąży do

1 http://budownictwo.wnp.pl/ruszaja-prace-na-szybka-koleja-z-polski-do-czech-i-niemiec,241056_ 1_0_0.html [dostęp 28.03.2017]. 
tworzenia sprawnego i efektywnego systemu transportowego poprzez wdrażanie wysokiej jakości rozwiązań umożliwiających swobodny przepływ ludzi, towarów i usług z zachowaniem zasad zrównoważonego rozwoju. Zwiększająca się mobilność mieszkańców Europy generuje popyt na usługi transportowe, co sprawia, że problemy kongestii i zanieczyszczenia środowiska przybierają na sile. Efektywne wykorzystanie dostępnych środków transportu w różnych kombinacjach ma sprzyjać optymalnemu i zrównoważonemu wykorzystaniu zasobów (Towpik, 2012). Idea transportu intermodalnego, która opiera się między innymi na wykorzystaniu w przewozach więcej niż jednej gałęzi transportu, jest w pełni zgodna z założeniami Europejskiej Strategii Rozwoju Zrównoważonego i polityki transportowej Unii Europejskiej (Huderek-Glapska, 2010: 47-54)

W kontekście transportu lotniczego, który jest najdynamiczniej rozwijającą się gałęzią transportu problemy zatłoczenia portów lotniczych i terenów wokół nich oraz emisji zanieczyszczeń i hałasu są szczególnie widoczne. Rozwój systemów łączących transport lotniczy z innymi gałęziami transportu - szczególnie z transportem kolejowym - w efektywną sieć transportu intermodalnego jest jednym z rozwiązań proponowanych przez Komisję Europejską, które ogranicza problemy kongestii i zanieczyszczenia środowiska (Huderek-Glapska, 2010: 47-54).

Celem niniejszego artykułu jest weryfikacja perspektywiczna rozwoju portów lotniczych w kontekście rozwoju innowacyjnej technologii kolei dużych prędkości w Polsce. W części teoretycznej artykułu przedstawiono elementy rozwoju kolei dużych prędkości na świecie. W części badawczej pracy dokonano analizy prognozowania metodą najmniejszych kwadratów przewozów pasażerskich i towarowych dla dwóch portów lotniczych w Polsce, weryfikując tezę zwiększenia możliwości realizacji przewozów intermodalnych, łączących transport kolejowy i lotniczy.

\section{Kolej dużych prędkości}

Kolej dużych prędkości najbardziej rozwinęła się w Chinach, Japonii, Francji, Niemczech, Hiszpanii, Włoszech, Wielkiej Brytanii oraz Korei Południo$w_{e j}^{2}$. Duży wpływ na rozwój KDP ma tzw. kongestia systemów transportowych. W głównej mierze chodzi o nasycenie ruchu w transporcie samochodowym oraz wzmożony ruch w transporcie lotniczym. Mowa oczywiście o korkach tworzących się w godzinach szczytu oraz o portach lotniczych, które często działają na granicy swojej przepustowości.

2 https://pl.wikipedia.org/wiki/Kolej_du\%C5\%BCych_pr\%C4\%99dko\%C5\%9Bci\#Kolej_du.C5. BCych_pr.C4.99dko.C5.9Bci_w_Polsce [dostęp 28.03.2017]. 
$\mathrm{Na}$ tym tle KDP oferują możliwość przewiezienia potencjalnie bardzo dużej liczby pasażerów, $\mathrm{z}$ większą prędkością niż pozwalają na to samochody i uniknięciem zatorów drogowych ${ }^{3}$.

Przewaga kolei dużych prędkości nad transportem samochodowym polega głównie na większym bezpieczeństwie oraz możliwości uzyskania dużo większej prędkości przejazdu na wybranych trasach (Wright, 2009). Z KDP korzysta coraz większa liczba pasażerów w celach prywatnych, ponieważ bilety są dużo tańsze niż w przypadku połączenia lotniczego (na terenie jednego państwa). Czas podróży koleją dużych prędkości można porównać do czasu podróży samolotem. Pomimo tego, że sam czas przelotu jest krótszy, to procedury odpraw, wsiadania oraz wysiadania z samolotu są o wiele bardziej czasochłonne i skomplikowane niż w KDP. Pociągi posiadają minimalne opóźnienia, np. w Japonii Shinkansen posiada ok. 36 sekund opóźnienia rocznie (Stolarewicz, 2015).

Dla porównania, jednym z głównych połączeń KDP w Japonii jest Tokio-Niigata. Długość tej trasy to ok. $340 \mathrm{~km}$, a czas podróży to zaledwie 120 minut (Stolarewicz, 2015). W Polsce jednym z głównych połączeń jest Warszawa-Gdańsk. Połączenie kolejowe tych miast ma długość ok. $330 \mathrm{~km}$, a czas podróży najszybszym połączeniem wynosi 166 minut $^{4}$.

Przewóz ludzi oraz towarów w każdym rodzaju transportu rozwija się z roku na rok. Połączenia KDP są konieczne, aby jeszcze szybciej rozwijać różne gałęzie transportu w Polsce.

\section{Prognozy wielkości przewozów pasażerskich i towarowych dla rozpatrywanych portów lotniczych}

W niniejszej części badawczej artykułu dokonano prognozy rozwoju dwóch portów lotniczych, istotnych z punktu widzenia rozwoju kolei dużych prędkości. Połączenie portów lotniczych koleją dużych prędkości dotyczy największego w Polsce Portu Lotniczego im. F. Chopina w Warszawie oraz trzeciego pod względem liczby odprawionych pasażerów - Portu Lotniczego im. Lecha Wałęsy w Gdańsku (Stolarewicz, 2015). Do analizy prognostycznej przewozów użyto klasycznej metody najmniejszych kwadratów w oparciu o dane historyczne największych portów lotniczych w Polsce.

3 Tamże.

4 http://rozklad-pkp.pl/ [dostęp 28.03.2017]. 


\subsection{Port Lotniczy im. Lecha Wałęsy w Gdańsku}

Statystyki ruchu w Porcie Lotniczym im. Lecha Wałęsy w Gdańsku w ostatnich latach przedstawiono w tabeli 1 - dla przewozów pasażerskich oraz w tabeli 2 - dla przewozów towarowych.

Tabela 1. Statystyka przewozu pasażerów w Porcie Lotniczym im. Lecha Wałęsy w Gdańsku

\begin{tabular}{|c|c|}
\hline Rok & Liczba pasażerów \\
\hline 2013 & 2842000 \\
\hline 2014 & 3288180 \\
\hline 2015 & 3706108 \\
\hline 2016 & 4010864 \\
\hline
\end{tabular}

Źródło: Towpik, 2012.

Tabela 2. Statystyka przewozu towarów w Porcie Lotniczym im. Lecha Wałęsy w Gdańsku

\begin{tabular}{|c|c|}
\hline Rok & Cargo [t] \\
\hline 2012 & 4851 \\
\hline 2013 & 4918 \\
\hline 2014 & 5658 \\
\hline 2015 & 5162 \\
\hline
\end{tabular}

Źródło: Urząd Lotnictwa Cywilnego, Statystyki i analizy rynku transportu lotniczego, http:// www.ulc.gov.pl/pl/regulacja-rynku/397-statystyki-i-analizy-rynku-transportu- lotniczego/3724statystyki-wg-portow-lotniczych [dostęp 28.03.2017].

Prognozę liniową przewozów pasażerskich dla Portu Lotniczego im. Lecha Wałęsy w Gdańsku przedstawiono na wykresie 1. Jak wynika z tego wykresu, przewidywany przyrost przewozów pasażerów będzie większy w kolejnych latach. W tabeli 3 przedstawiono prognozowaną liczbę pasażerów w kolejnych latach.

Tabela 3. Prognozowana liczba pasażerów w kolejnych latach dla Portu Lotniczego im. Lecha Watęsy w Gdańsku

\begin{tabular}{|c|c|}
\hline Rok & Prognozowana liczba pasażerów \\
\hline 2017 & 4442918 \\
\hline 2018 & 4835370 \\
\hline 2019 & 5227822 \\
\hline
\end{tabular}

Źródto: opracowanie własne. 


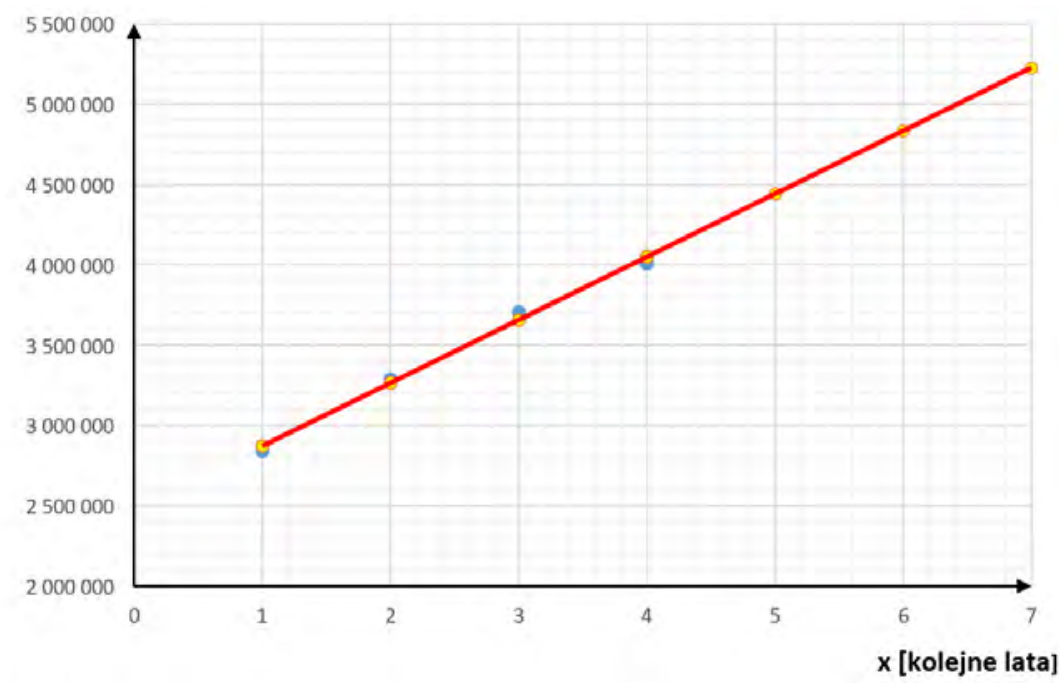

Wykres 1. Prognoza przewozów pasażerskich w kolejnych latach $(2017,2018,2019)$ dla Portu Lotniczego im. Lecha Wałęsy w Gdańsku

Źródło: opracowanie własne.

Podobną analizę przeprowadzono dla przewozów towarowych. Prognozę liniową przewozów towarowych dla Portu Lotniczego im. Lecha Wałęsy w Gdańsku zaprezentowano na wykresie 2, natomiast w tabeli 4 przedstawiono prognozę ilości towarów przewiezionych w kolejnych latach. Tu również przewidywany jest przyrost.

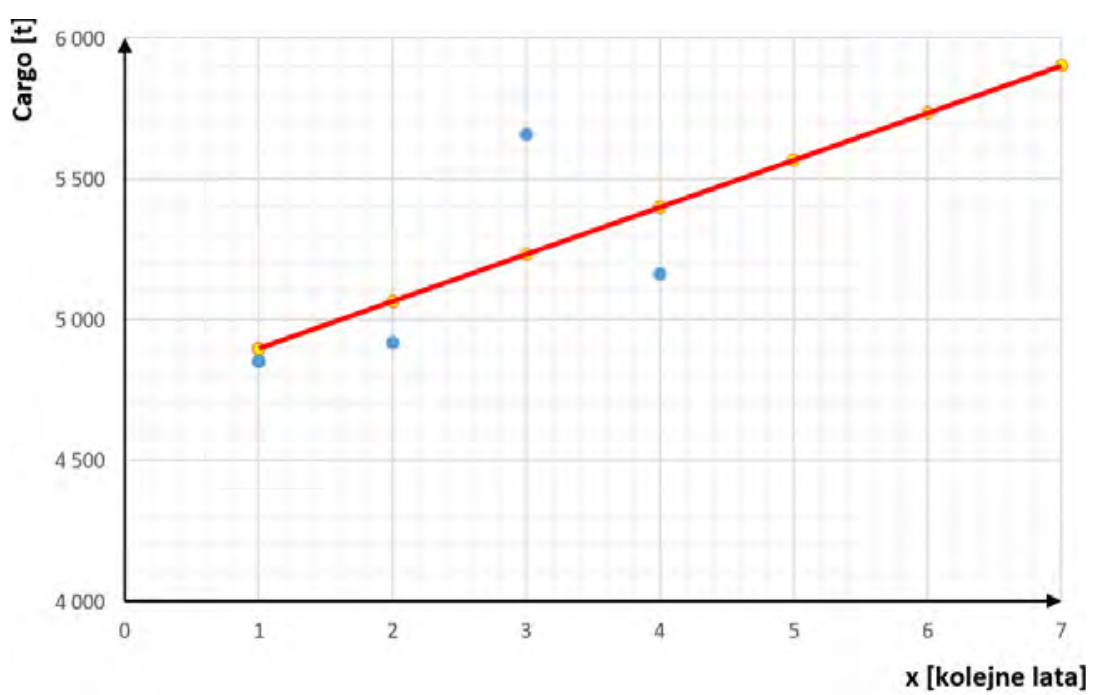

Wykres 2. Prognoza przewozu towarów w kolejnych latach $(2016,2017,2018)$ dla Portu Lotniczego im. Lecha Wałęsy w Gdańsku

Źródło: opracowanie własne. 
Tabela 4. Prognoza przewozów cargo w kolejnych latach dla Portu Lotniczego im. Lecha Wałęsy w Gdańsku

\begin{tabular}{|c|c|}
\hline Rok & Prognoza cargo [t] \\
\hline 2016 & 5565,5 \\
\hline 2017 & 5732,8 \\
\hline 2018 & 5900,1 \\
\hline
\end{tabular}

Źródto: opracowanie własne.

\subsection{Port Lotniczy im. F. Chopina w Warszawie}

Statystyki ruchu w Porcie Lotniczym im. F. Chopina w Warszawie z ostatnich lat przedstawiono w tabelach 5 i 6.

Tabela 5. Statystyka przewozu pasażerów w Porcie Lotniczym im. F. Chopina w Warszawie

\begin{tabular}{|c|c|}
\hline Rok & Liczba pasażerów \\
\hline 2013 & 10669879 \\
\hline 2014 & 10574539 \\
\hline 2015 & 11186688 \\
\hline 2016 & 12795365 \\
\hline
\end{tabular}

Źródło: opracowanie własne na podstawie Urząd Lotnictwa Cywilnego, Statystyki i analizy rynku transportu lotniczego, http://www.ulc.gov.pl/pl/regulacja-rynku/397-statystyki-i-analizyrynku-transportu- lotniczego/3724-statystyki-wg-portow-lotniczych [dostęp 28.03.2017].

Tabela 6. Statystyka przewozu towarów w Porcie Lotniczym im. F. Chopina w Warszawie

\begin{tabular}{|c|c|}
\hline Rok & Cargo [t] \\
\hline 2013 & 48219,1 \\
\hline 2014 & 53474,6 \\
\hline 2015 & 58282,4 \\
\hline 2016 & 72186,4 \\
\hline
\end{tabular}

Źródło: opracowanie własne na podstawie Urząd Lotnictwa Cywilnego, Statystyki i analizy rynku transportu lotniczego, http://www.ulc.gov.pl/pl/regulacja-rynku/397-statystyki-i-analizyrynku-transportu- lotniczego/3724-statystyki-wg-portow-lotniczych [dostęp 28.03.2017].

Prognozę liniową dla Portu Lotniczego im. F. Chopina w Warszawie przedstawiono na wykresie 3. Jak wynika z wykresu, przewidywany przyrost przewo- 
zów pasażerów, tak jak w przypadku Portu Lotniczego im. Wałęsy, będzie większy w kolejnych latach. W tabelach 7 i 8 przedstawiono prognozowane liczby przewozu pasażerów i towarów dla lat 2017-2018.

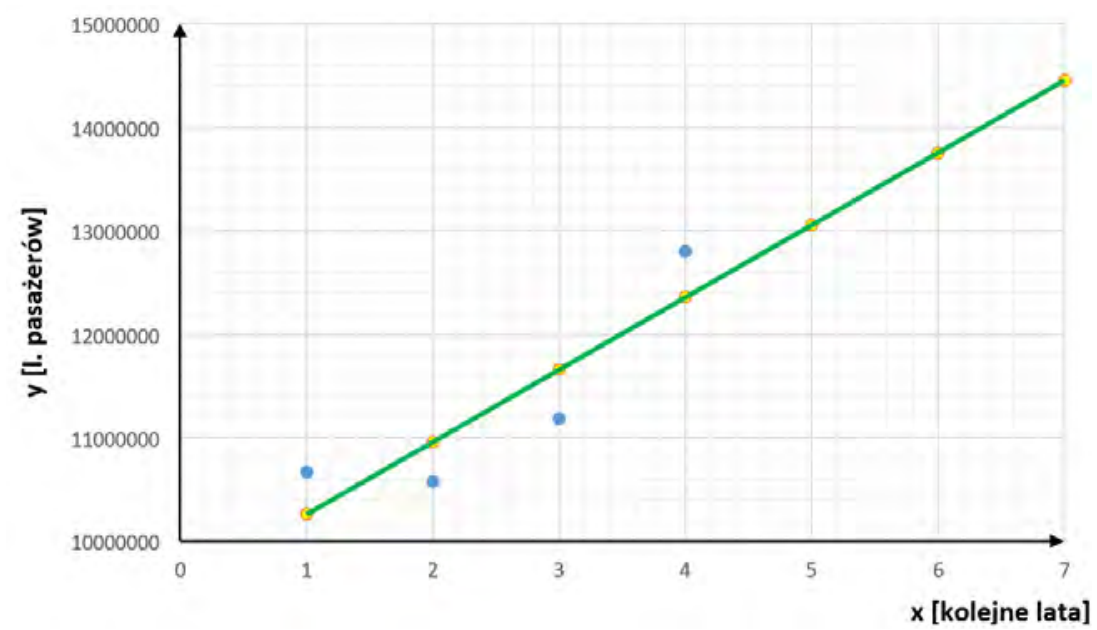

Wykres 3. Prognoza liczby pasażerów w kolejnych latach $(2017,2018,2019)$ w Porcie Lotniczym im. F. Chopina w Warszawie

Źródło: opracowanie własne.

Tabela 7. Prognozowana liczba pasażerów w kolejnych latach dla Portu Lotniczego im. F. Chopina w Warszawie

\begin{tabular}{|c|c|}
\hline Rok & Prognozowana liczba pasażerów \\
\hline 2017 & 13053769,5 \\
\hline 2018 & 13752630,2 \\
\hline 2019 & 14451490,9 \\
\hline
\end{tabular}

Źródło: opracowanie własne.

Tabela 8. Prognoza przewozów cargo w kolejnych latach w Porcie Lotniczym im. F. Chopina w Warszawie

\begin{tabular}{|c|c|}
\hline Rok & $\begin{array}{c}\text { Prognozowana wielkość przewozów } \\
\text { cargo [t] }\end{array}$ \\
\hline 2017 & 77218,05 \\
\hline 2018 & 84889,02 \\
\hline 2019 & 92559,99 \\
\hline
\end{tabular}

Źródło: opracowanie własne. 


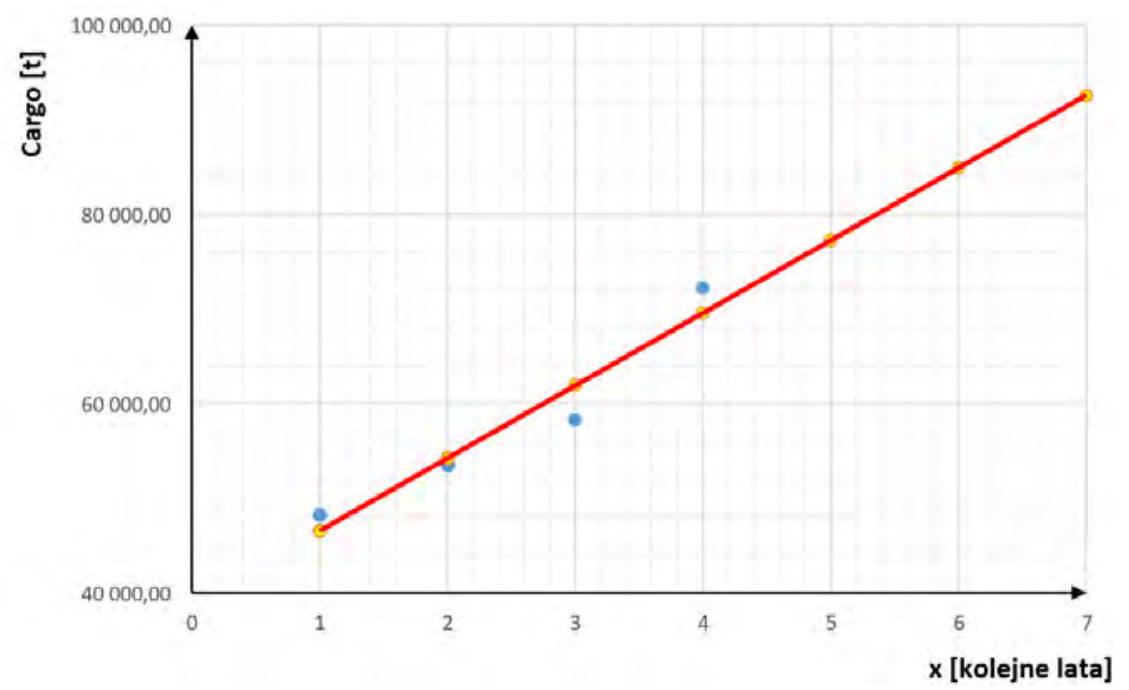

Wykres 4. Prognoza przewozu towarów w kolejnych latach $(2017,2018,2019)$ w Porcie Lotniczym im. F. Chopina w Warszawie Źródto: opracowanie własne.

\section{Podsumowanie}

Z przeprowadzonych wyliczeń prognozowanych wielkości przewozów pasażerskich i towarowych można łatwo wywnioskować, że liczba przewożonych pasażerów, jak i towarów z roku na rok jest coraz większa. KDP będzie zatem bardzo dobrym rozwiązaniem dla połączenia tych portów. Zarówno pasażerowie, jak i towary będą się szybciej przemieszczać, co pozwoli na zaoszczędzenie czasu, poprawi komfort podróżowania, a koszty związane z transportem między portami ulegną zmniejszeniu. Niestety, wykorzystanie kolei dużych prędkości wymaga budowy nowej infrastruktury, gdyż stan aktualnej nie pozwala w pełni wykorzystać potencjału nowoczesnych rozwiązań. Nowa infrastruktura nie tylko otwiera drogę do zakupu nowych zestawów, ale także umożliwia eksploatację już posiadanych, takich jak Dart czy Pendolino. 


\section{Bibliografia}

Huderek-Glapska S., (2010), Port lotniczy w systemie transportu intermodalnego, „LogForum, no. 1 (6), s. 47-54.

Raczyński J., (2008), Rzq̨dowy program budowy linii dużych prędkości w Polsce, „Technika Transportu Szynowego", nr 9, s. 17-26.

Rydzyński P., (2014), Rok 2014 na kolei: Pendolino, dworce, budowa PKM, ekspansja Cargo, dyskusja o PR-ach, http://www.rynek-kolejowy.pl/wiadomosci/rok-2014-na-kolei-pendolinodworce-budowa-pkm-ekspansja-cargo-dyskusja-o-prach-24011.html [dostęp 28.03.2017).

Rząsa D., (2011), Szybka kolej w Polsce: zobacz, jak będq wyglądać polskie Pendolino za 2,6 mld zt, http://forsal.pl/artykuly/518766,szybka-kolej-w-polsce-zobacz-jak-beda- wygladac-polskie-pendolino-za-2-6-mld-zl.html [dostęp 28.03.2017].

Stolarewicz M., (2015), Shinkansen - jak wygląda podróż najszybszym pociągiem świata w Japonii?, https://www.blogglobtrotera.pl/shinkansen-jak-wyglada-podroz- najszybszym-pociagiem-swiata-w-japonii/ [dostęp 28.03.2017].

Towpik K., (2012), Koleje dużych prędkości: infrastruktura drogi kolejowej, Oficyna Wydawnicza Politechniki Warszawskiej, Warszawa.

Urząd Lotnictwa Cywilnego, Statystyki i analizy rynku transportu lotniczego, http://www.ulc.gov. $\mathrm{pl} / \mathrm{pl} /$ regulacja-rynku/397-statystyki-i-analizy-rynku-transportu- lotniczego/3724-statystyki-wg-portow-lotniczych [dostęp 28.03.2017].

Wright R., (2009), Szybka koleją w Europie jeździ się jeszcze szybciej, http://forsal.pl/artykuly/379144,szybka-koleja-w-europie-jezdzi-sie-jeszcze-szybciej.html [dostęp 28.03.2017].

\section{Źródta internetowe}

http://budownictwo.wnp.pl/ruszaja-prace-na-szybka-koleja-z-polski-do-czech-i-niemiec, 241056_1_0_0.html [dostęp 28.03.2017].

http://rozklad-pkp.pl/ [dostęp 28.03.2017].

https://pl.wikipedia.org/wiki/Kolej_du\%C5\%BCych_pr\%C4\%99dko\%C5\%9Bci\#Kolej_du.C5.

BCych_pr.C4.99dko.C5.9Bci_w_Polsce [dostęp 28.03.2017].

https://pl.wikipedia.org/wiki/Plik:POL_rail_Y.svg [dostęp 28.03.2017]. 